\title{
Morpho-Palynological Studies On The Angiospermic Fern Cyrtomium Cyrotideum C. Chr; (Syn: Polystichium Falcatum).
}

\author{
Ashfaq Ahmed Awan ${ }^{1}$, Zahid Iqbal Awan ${ }^{2 *}$ and Fiaz Aziz Minhas ${ }^{2}$ \\ ${ }^{1}$ Department of Botany, University of Azad Jammu \& Kashmir, Muzaffarabad, 13100, Pakistan \\ ${ }^{2}$ Department of Chemistry, University of Azad Jammu \& Kashmir, Muzaffarabad, 13100, Pakistan
}

\begin{abstract}
The Angiospermic fern Cyrtomium cyrotideum C. Chr. was collected from Chikar and Kachelli, under the shade of Pinus wallichianum (A. B. Jackson) at an altitude of 7000 feet, Jehlum Valley District Muzaffarabad Azad Kashmir. The sporangia globose, sori are small and scattered, stripes tufted, densely clothed below with large dark scales, scattered, texture coriaceous with naked surface, the upper surface glossy with primary veins from the midrib of the pinnae. Each meristele has thick walled pericycle within which a crescent-shaped xylem is located with exarch protoxylem. Phloem cells are thin walled and filled to make a round mass of the cells. Average size of capsule is $250 \mu x 100 \mu$ across wide, $180 \mu$ in height. Spore manostele is $90 \mu$ thick, isospore, bilateral, proximal, flat, perine, and delicate. Spore dimension is $92 \times 66 \mu$. Distal surface heavily warty with the exine thickness of $3.5 \mu$.
\end{abstract}

\section{Introduction}

The genus Cyrtomium is placed in the family Pteridaceae and sub family Dryopteridaceae, which includes 25 genera. Leave texture of Cyrtomium cyrotideum is leathery, having xero-phytic characters. These Dryopteroid and leptosporangiate ferns are grouped together as Conioragamme affinis Wall. Onychium cotiguum Wall Athyrium flix-fomina (L) Roth, Cystopters fragalis (L) Berth, Polystichum nigroplacum (Christ) Diels and contains other ferns but the genus Cyrtomium may contain only one specie. Cyrtomium cyrotideum has been recorded from Hazara, Swat and Nathia Galli in Pakistan. The venation may be open as in Polystichum while it is closed reticulation in Cyrtomium. This close type of venation is rather advanced order open type. The ferns of this group have varied form of sori [1]. The author had visited Jhelum Valley District Muzaffarabad in Azad Kashmir, representing home land for certain beautiful ferns. It was observed that the plants like Cyrtomium were very common near Serimang in Poonch [2]. He identified 127 ferns from Pakistan [3], in his comprehensive account of the ferns of Kaghan Valley which was important diversified ferns. The contribution of these workers was strengthened and ultimately enlisted in the "Flora of Pakistan" [4]. Anatomy, sporangial structure and spore morphology have not been investigated. The present study is an effort to add some information about the rare angiospermic fern Cyrtomium cyrotideum after earth quake (8th October 2005) because this fern is totally extinct from the Kachili area.

\section{Materials and Methods}

The fresh specimens were collected along with rhizome. The material was preserved in acetic acid and alcohol (1:3) till further use. The clearing of leaflets/fronds were made according to the technique [5]. The material $(500 \mathrm{~g})$ was kept in aqueous solution of chloral hydrate which was obtained by dissolving $200 \mathrm{~g}$ in $1000 \mathrm{ml}$ of distilled water for 5 hours. The fronds were washed thoroughly with distilled water and chlorinated [6]. The fronds were then stained with alcoholic basic fuchsine (saturated solution of basic fuchsine in ethanol) was filtered in brown colored glass bottle. Ammonium solution (33\%) was added drop by drop to alcoholic basic fuchsine till the red color changes to pale yellow, filtrate was used to stain.

The plants fronds, basic section, $(8 \times 6$ inches) with sporangium and spores were mounted in Euperal on a glass plate. The sporangia were detached from the fertile fronds with the help of needle under binocular microscope and the mounted in glycerin jelly on a glass slide. For spore investigations the sori were crushed with glass rod and pass through 1.5 inch dia funnel placed in a centrifuge tube and plucked with loosely placed glass wool.

The sieved spores were treated with $\mathrm{KOH}$ solution for the removal of solids and humic acid. After chlorination the spores were mounted in $2 \%$ saffranin. The mounted slides were sealed using synthetic enamel on a ringing disc. For anatomical studies the Transverse section of the rachis were made. After staining with $2 \%$ saframin solution the sections were mounted in Euperal for microscopic studies. Most of the observational work was carried out using PZO Microscope No. 5196. Palaenological investigations of spores were also studied under the same microscope and terminology for the description has been borrowed from Erdtman (1954) and Falgri and Irorsen (1950). The whole mount of fronds or leaflets was photographed using Nikon Camera. 


\section{Results and Discussions}

In Cyrtomium cyrotideum the sori are small, copious and scattered. Indusia peltate and shed at very easily state (see fig $1 \& 2$ ). Close type of venation in a leaflet of cleared specimen has been shown as in fig. 3 . Morphologically the rachis of Cyrtomium cyrotideum has stripe tufted having large dark scales from 1-2 feet long by 6-9 inches broad, pinnate, pinna numerous lower one staked, orate acurinate. Falcate 4-6 inches long, the upper side narrowed, interiorly glossy sometimes base auricled, rounded or obliquely truncated, texture coriaceous, glossy, surface naked, primary veins from the midrib of the pinnae (fig. 4).

Anatomically the transverse section of the rachis souts the following textures, Outer cortex is seclerenchymatous compresses of many layers of cells. The ground tissue is with tightly packed parenchyma with four meristele, two smaller and two larger, smaller towards the dorsal surface and larger towards the ventral surface. Xylem is located with exarch protoxylem. Phloem thin walled, filled with a round mass of celli (fig. 5). Similarly sporangial morphology shows sporangial stalked of three cells. Capsule away during isolation and average size is $250 \mu$ wide, $18 \mu$ in height and $90 \mu$ thick. Stomium is transverse, stomium cells in corporate, the annulus is complete and placed vertically around the capsule. Average number of annuls cells are 12-14 and individual annulus cells $25 \times 25 \mu$ across and $20 \mu$ deep and $20 \mu$ in length. Number of spores per sporangium is unknown (fig. 6). palaenolgically sori (Cyrtomium cyrotideum ) is isospore, monolete, bilateral, proximal surface flat, on the upper surface discernable sinurus, perine delicate, dorsal surface heavily warty exine thickness is $3.5 \mu$. (Fig. $7 \& 8$ )

\section{References}

[1]. P. N. Mehra, Macronesian heathland. In: Heathlanda of the world (Ed. E. L. Specht), (Elsevier publishing Co., New York, 1939)

[2]. R. R. Stewart, 1957. The ferns and ferns allies of West Pakistan and Kashmir, Biologia, 3(2), 1957, 1-32.

[3]. A. H. Sheikh, Ferns of Kaghan valley, Pak. Jour. Sci. Res., 14(4), 1962, 195-209.

[4]. R. R. Stewart, E. Nasir and S. I. Ali, Flora of West Pakistan, ( An annotated catalogues of Vascular Plants of West Pakistan and Kishmir, Karachi University, 1972) 1028.

[5]. A. A. Bhutta and A. Sadiq, A modified technique to study the xylem of whole plants or plant organs, Bull. Palaeobot. Palynol. Club Pak., 1, 1987, 43-45.

[6]. A. A. Bhutta, On the spore (including germinating spores) of Horneophyton (Hornea) Lignieri (Kidston and Lang) Barghoom Darrab (1938). Pak. J. Bot., 5(1), 1973, 45-55.

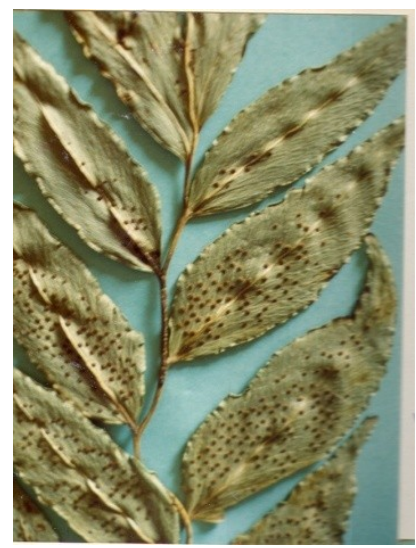

Figure 1

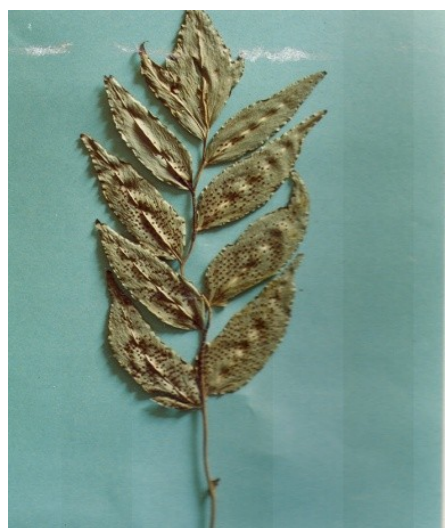

Figure 3



Figure 2

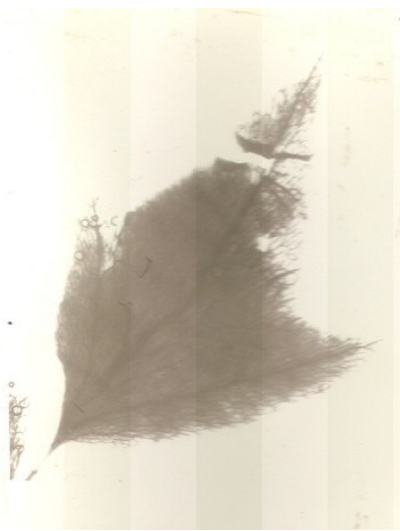

Figure 4 


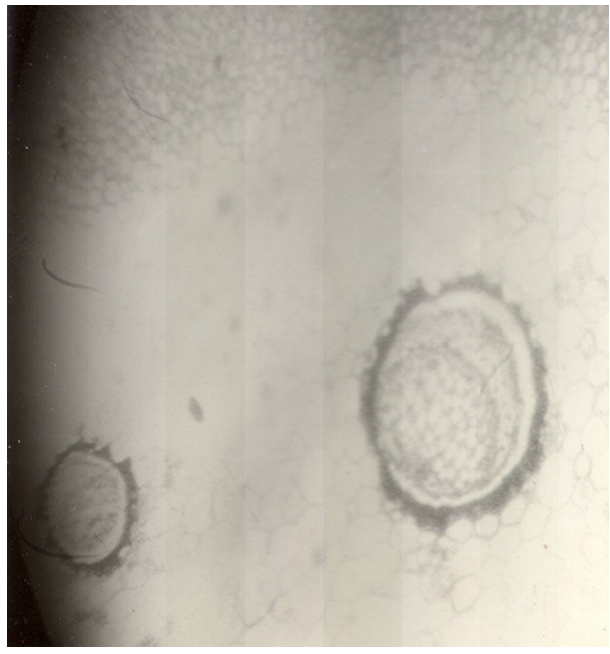

Figure 5



Figure 6



Figure 7

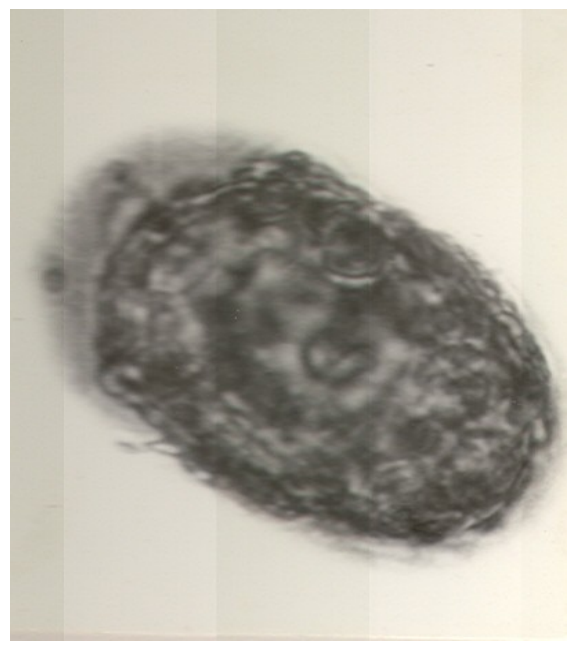

Figure 8 